LINGUA, Vol. 16, No. 1, Maret 2019

p ISSN: 1979 9411; e ISSN: 2442 238X

Http://lingua.pusatbahasa.or.id; Email: presslingua@gmail.com

Center of Language and Cultural Studies, Surakarta, Indonesia

Prabowo, Adiprasetio. 2019. Pengaruh Penggunaan Campur Kode dalam Pembelajaran Bahasa Indonesia pada Siswa SMPN 7 Woja Dompu.

Lingua (2019), 16(1): 93 108. DOI: 10.30957/lingua.v16i1.577.

\title{
PENGARUH PENGGUNAAN CAMPUR KODE DALAM PEMBELAJARAN BAHASA INDONESIA PADA SISWA SMPN 7 WOJA DOMPU
}

\section{Adiprasetio Prabowo}

\author{
Program Studi Magister Pendidikan Bahasa Indonesia \\ Program Pasca Sarjana Universitas Mataram \\ Jl. Pemuda No. 35 Mataram 83125, Nusa Tenggara Barat \\ Email : adipdanrabowo850@gmail.com
}

\begin{abstract}
This study explores the use of code-mixing in Indonesian language learning used in the classroom of SMPN 7 Woja Dompu. The design of the study is a descriptive qualitative methods that assigned students and teachers in SMPN 7 Woja. Data were collected using documentation, interviews and translations. This results fo this study show Indonesian language learning in is conducted using code-mixing between bahsa Indonesia and local language in terms of words, phrases, and clauses. Mixed-shaped code words occur in total 95 words, phrases shaped mixing 107, and code-mixing clause shaped 43 . The use of code-mixing that dominate in this research is mixed in the form of code phrases. The use of code-mixing in the learning affects teachers to facilitate learning, but students accept the code-mixing as their usual daily interactions.
\end{abstract}

Keywords: code-mixing, phrases, clauses, mixed-shaped.

DOI: $10.30957 /$ lingua.v16i1.577.

\section{PENDAHULUAN}

Dalam situasi pertuturan sering ditemukan orang bertutur dengan menggunakan bahasa tertentu tiba-tiba mengganti bahasanya. Mengganti bahasa diartikan sebagai tindakan mengalihkan bahasa maupun mencampur antara bahasa satu dengan bahasa lainnya. Hal ini terjadi karena masyarakat yang berdwibahasa dan multilingual, mereka dapat menggunakan bahasa daerahnya sebagai bahasa pertama yang biasanya merupakan bahasa ibu (BI) dan bahasa kedua adalah bahasa Indonesia (B2) sebagai bahasa nasional. Fenomena ini dapat terjadi baik pada situasi kebahasaan nonformal misalnya percakapan sehari-hari dan kebahasaan formal, seperti di lembaga-lembaga pendidikan. Bahasa sebagai sarana komunikasi sangat penting peranannya bagi kehidupan manusia. Dengan bahasa seseorang bisa berkomunikasi dengan siapapun dan di negara manapun. Dengan bahasa seseorang bisa mendapatkan berbagai informasi dan ilmu pengetahuan. Dalam berkomunikasi, terkadang orang tidak hanya menggunakan satu bahasa saja.

Dalam pembelajaran di lembaga pendidikan, bahasa merupakan sarana pengantar informasi. Hal ini sesuai dengan kedudukan bahasa Indonesia sebagai bahasa negara yaitu berfungsi sebagai bahasa pengantar resmi di lembaga-lembaga pendidikan 
LINGUA, Vol. 16, No. 1, Maret 2019

p ISSN: 1979 9411; e ISSN: 2442 238X

Http://lingua.pusatbahasa.or.id; Email:presslingua@gmail.com

Center of Language and Cultural Studies, Surakarta, Indonesia

Prabowo, Adiprasetio. 2019. Pengaruh Penggunaan Campur Kode dalam Pembelajaran Bahasa Indonesia pada Siswa SMPN 7 Woja Dompu.

Lingua (2019), 16(1): 93 108. DOI: 10.30957/lingua.v16i1.577.

(Halim, 1976:145). Bahasa sebagai media komunikasi tentunya merupakan bagian yang vital dan utama dalam hidup ini karena tanpa bahasa sulit bagi kita untuk mengerti dan memahami arti maksud dari perkataan orang lain. Demikian pula halnya dalam pembelajaran di kelas, bahasa sebagai alat interaksi memegang peranan penting dalam aktivitas pembelajaran. Oleh karena itu, pemilihan bahasa memiliki pengaruh yang sangat besar terhadap keberhasilan lawan tutur dalam mengartikan pesan yang disampaikan penutur.

Berkaitan dengan penggunaan bahasa dalam pembelajaran, guru dan siswa dalam hal ini cenderung berdwibahasa sehingga konsekuensi logis dari adanya kedwibahasaan ini adalah timbulnya campur kode. Menurut Korzybski dalam Mulyana (2016:7) menyatakan bahwa kemampuan manusia berkomunikasi menjadikan mereka "Pengikat waktu". Pengikat waktu merujuk pada kemampuan manusia untuk mewariskan pengetahuan dari generasi ke generasi dan dari budaya ke budaya. Fenomena ini terjadi dalam pembelajaran di SMPN 7 Woja Dompu yaitu guru dan siswa menggunakan dua bahasa yaitu bahasa Indonesia dan bahasa Dompu dalam pembelajaran. Bilamana seseorang mencampurkan dua/lebih bahasa atau ragam bahasa dalam suatu tindak berbahasa tampa ada sesuatu dalam situasi berbahasa yang menuntut percampuran bahasa (Nababan dalam Aslinda dan Syafyahya, 2010:24).

Apa yang mereka lakukan, sebenarnya akan mengurangi rasa nasionalisme terhadap bahasa Indonesia dan telah keluar dari koridor kita sebagai bangsa Indonesia yang telah bertekad untuk menjunjung bahasa persatuan, bahasa Indonesia. Selain itu, para pendidik dan para pengambil kebijakan seharusnya kembali kepada aturan tertinggi dalam penyelenggaraan republik ini, yaitu Undang-Undang Dasar 1945 Pasal 36 yang menyatakan bahwa "Bahasa negara ialah bahasa Indonesia," dan sebagaimana tersirat dalam Sumpah Pemuda 28 Oktober 1928 ikrar ketiga yang berbunyi "Kami putra dan putri Indonesia mengaku berbahasa yang satu, bahasa Indonesia."

Berdasarkan paparan di atas sudah sangat jelas bahwa bahasa Indonesia merupakan bahasa yang dipergunakan dalam berkomunikasi oleh warga negara Indonesia terutama dalam dunia pendidikan. Cinta bahasa Indonesia peserta didik akan terbentuk apabila para pendidik memberikan contoh yang baik dan memberikan arahan untuk menggunakan bahasa Indonesia yang baik dan benar, karena siswa akan belajar dari seorang guru yang mengajarnya. Guru "Digugu dan ditiru" sehingga tidak salah jika siswa meniru atau mengikuti apa yang disampaikan dan dilakukan gurunya. Selain itu, guru bertanggung jawab atas tercapainya hasil belajar yang diinginkan (Raka Joni dalam Dimyati dan Mudjiono, 2015:28). Terutama hasil belajar yang diinginkan adalah guru dan siswa lancar dalam menggunakan bahasa Indonesia yang baik dan benar.

Kekhawatiran dari sisi muatan keilmuan, tentu sangat diragukan karena munculnya guru dan siswa yang menggunakan bahasa daerah dalam pembelajaran. Kita bisa membayangkan kualitas pendidikan di Indonesia tatkala semua peserta didik di sekolah-sekolah bahasa Indonesianya belum mapan, ketika mereka harus berinteraksi dengan pendidik, maka pendidik berusaha semaksimal mungkin untuk menggunakan bahasa daerah dalam menyampaikan materinya. Akhirnya yang terjadi, para pendidik lebih berkonsentrasi pada penggunaan bahasa daerah daripada menjelaskan materi dengan menggunakan bahasa Indonesia. Tentu intensitas penggunaan bahasa daerah 
LINGUA, Vol. 16, No. 1, Maret 2019

p ISSN: 1979 9411; e ISSN: 2442 238X

Http://lingua.pusatbahasa.or.id; Email:presslingua@gmail.com

Center of Language and Cultural Studies, Surakarta, Indonesia

Prabowo, Adiprasetio. 2019. Pengaruh Penggunaan Campur Kode dalam Pembelajaran Bahasa Indonesia pada Siswa SMPN 7 Woja Dompu.

Lingua (2019), 16(1): 93 108. DOI: 10.30957/lingua.v16i1.577.

lebih mendominasi daripada penggunaan bahasa Indonesia. Hal ini menimbulkan kekhawatiran bahwa semakin lama kekuatan kaidah bahasa Indonesia dan intensitas berbicara menggunakan bahasa Indonesia, baik dari segi lafal, EYD maupun kosakatakosakatanya akan semakin tidak diperhatikan.

Dalam penelitian ini peneliti melakukan penelitian dengan alasan bahwa siswa di sekolah SMPN 7 Woja Dompu masih kental dengan penggunaan bahasa daerah sehingga guru harus menggunakan bahasa daerah agar peserta didik mengerti penjelasan materi pelajaran yang disampaikan pada saat pembelajaran berlangsung. Oleh sebab itu, tujuan penelitian yaitu Pendeskripsian bentuk penggunaan campur kode dan pengaruh penggunaan campur kode dalam pembelajaran bahasa Indonesia di kelas VII SMPN 7 Woja Dompu tahun pelajaran 2016/2017.

\section{METODE}

\subsection{Rancangan Penelitian}

Rancangan penelitian dimaksudkan untuk memberikan gambaran tentang penelitian yang akan dilakukan. Rancangan penelitian adalah cara berfikir dengan menggunakan langkah-langkah sistematik dalam penelitian. Metode yang digunakan dalam penelitian ini adalah metode deskriptif kualitatif. Metode penelitian deskripsi kualitatif yaitu prosedur penelitian yang menghasilkan data deskriptif berupa kata-kata tertulis atau lisan dari orang-orang dan perilaku yang dapat diamati (Bogdan dan Guba dalam Suharsaputra, 2012:181). Penggunaan metode kualitatif pada penelitian ini merupakan strategi kerja dalam menganalisis objek penelitian berdasarkan rumusan masalah yang akan dipecahkan yaitu bentuk dan pengaruh penggunaan campur kode dalam pembelajaran bahasa Indonesia di kelas VII SMPN 7 Woja Dompu tahun pelajaran 2016/2017.

\subsection{Subjek Penelitian}

Subjek penelitian ini adalah guru mata pelajaran bahasa Indonesia berjumlah 1 orang dan siswa kelas VII.A dan VII.B. Kelas VII.A berjumlah 27 orang dengan perincian 14 orang laki-laki dan 13 orang perempuan, sedangkan kelas VII.B berjumlah 27 orang dengan perincian 12 orang laki-laki dan 15 orang perempuan sebagai sampel penelitian, dengan menggunakan teknik sampel bertujuan (purposive sampling). Sampel yang diambil dalam penelitian ini bertujuan untuk memperoleh data yang sesuai dan memenuhi kriteria yang dikehendaki dalam penelitian ini. Teknik purposive sampling mengambil sampel sumber data dengan pertimbangan tertentu, misalnya orang tersebut yang dianggap paling tahu, paling ahli dan sebagainya (Sugiyono, 2014:219). Selain itu, hal ini dilakukan untuk mempermudah peneliti dalam memperoleh data yang valid dan akurat tentang bentuk dan pengaruh penggunaan campur kode dalam pembelajaran bahasa Indonesia di kelas VII SMPN 7 Woja Dompu tahun pelajaran 2016/2017.

\subsection{Teknik Pengumpulan Data}

\subsubsection{Simak}

Metode simak merupakan metode yang dilakukan dengan penyimakan. Metode simak digunakan karena peneliti akan memperoleh data dengan cara menyimak 
LINGUA, Vol. 16, No. 1, Maret 2019

p ISSN: 1979 9411; e ISSN: 2442 238X

Http://lingua.pusatbahasa.or.id; Email:presslingua@gmail.com

Center of Language and Cultural Studies, Surakarta, Indonesia

Prabowo, Adiprasetio. 2019. Pengaruh Penggunaan Campur Kode dalam Pembelajaran Bahasa Indonesia pada Siswa SMPN 7 Woja Dompu.

Lingua (2019), 16(1): 93 108. DOI: 10.30957/lingua.v16i1.577.

penggunaan bahasa. Dalam hal ini, yang akan disimak adalah bahasa lisan. Dalam penelitian ini yang akan disimak yaitu penggunaan campur kode dalam pembelajaran bahasa Indonesia di kelas VII SMPN 7 Woja Dompu tahun pelajaran 2016/2017.

Metode ini memiliki teknik dasar yang berwujud teknik sadap, dikatakan demikian karena dalam praktik penelitian sesungguhnya penyimakan itu dilakukan dengan menyadap atau merekam pemakaian bahasa dari informan. Teknik sadap diikuti dengan teknik lanjutan yang berupa teknik simak libat cakap, simak bebas libat cakap, catat dan teknik rekam. Teknik simak libat cakap, maksudnya si peneliti melakukan penyadapan itu dengan cara berpartsiipasi dalam pembicaraan, dan menyimak pembicaraan. Dalam hal ini, si peneliti terlibat langsung dalam dialog. Adapun teknik simak bebas libat cakap, maksudnya si peneliti hanya berperan sebagai pengamat penggunaan bahasa oleh para informannya. Selanjutnya teknik catat adalah data yang dihasilkan dari teknik simak dapat langsung dicatat dalam kertas data. Pencatatan terhadap data kebahasaan dilakukan dengan transkripsi tertentu menurut kepentinganya. Jika tidak dilakukan pencatatan, si peneliti dapat melakukan perekaman, teknik rekam dimunkinkan terjadi jika bahasa yang diteliti adalah bahasa yang masih dituturkan oleh pemiliknya (Mahsun, 2013:92). Alat yang digunakan dalam metode simak ini adalah peneliti itu sendiri, Handphone, buku dan balpoin.Peneliti yang akan melakukan penyimakan, Handphone yaitu alat yang digunakan untuk merekam, mengambil gambar maupun video, sedangkan buku dan balpoin sebagai alat untuk mencatat.

\subsubsection{Dokumentasi}

Metode dokumentasi digunakan yaitu untuk memperoleh data langsung dari tempat penelitian, meliputi buku-buku yang relevan, peraturan-peraturan, laporan kegiatan, foto-foto, film dokumenter yang relevan dengan tujuan peneltian. Salah satu sumber informasi untuk penelitian dapat diperoleh melalui keterangan yang terdapat dalam dokumen.

Adapun data yang akan diambil melalui metode dokumentasi ini adalah gambaran umum SMPN 7 Woja Dompu, foto-foto pembelajaran bahasa Indonesia guru dan siswa di kelas VII SMPN 7 Woja Dompu tahun pelajaran 2016/2017. Data dokumentasi sangat diperlukan karena akan memperoleh data yang relevan dengan penelitian yang dilakukan peneliti. Alat yang digunakan dalam metode ini adalah kamera digital. Kamera digital adalah alat untuk mengambil gambar dalam penelitian yang dilakukan oleh peneliti.

\subsubsection{Wawancara}

Peneliti menggunakan metode wawancara yaitu untuk menemukan permasalahan dan ingin mengetahui hal-hal dari responden yang lebih mendalam. Dengan wawancara akan memperkaya data dan akan memperteguhnya. Wawancara dilakukan untuk memperoleh data tentang pengaruh penggunaan campur kode dalam pembelajaran bahasa Indonesia di SMPN 7 Woja Dompu tahun pelajaran 2016/2017. Metode wawancara yang digunakan peneliti adalah wawancara semiterstruktur. Wawancara semitersrtuktur ialah wawancara dalam pelaksanaanya lebih bebas. Tujuan 
LINGUA, Vol. 16, No. 1, Maret 2019

p ISSN: 1979 9411; e ISSN: 2442 238X

Http://lingua.pusatbahasa.or.id; Email: presslingua@gmail.com

Center of Language and Cultural Studies, Surakarta, Indonesia

Prabowo, Adiprasetio. 2019. Pengaruh Penggunaan Campur Kode dalam Pembelajaran Bahasa Indonesia pada Siswa SMPN 7 Woja Dompu.

Lingua (2019), 16(1): 93 108. DOI: 10.30957/lingua.v16i1.577.

dari wawancara jenis ini adalah untuk menemukan permasalahan secara lebih terbuka, di mana pihak yang diajak wawancara diminta pendapat, dan ide-idenya.

Dalam melakukan wawancara, peneliti perlu mendengarkan secara teliti dan mencatat apa yang dikemukakan oleh informan. Dalam melakukan wawancara, peneliti akan mengajukan pertanyaan dan guru beserta siswa-siswi yang memberikan jawaban atas pertanyaan itu. Adapun alat yang digunakan dalam metode ini yaitu beberapa lembar daftar pertanyaan. Sudah menjadi hal yang pasti bahwa daftar pertanyaan tersebut akan dibuat oleh peneliti untuk memperoleh jawaban dari responden, sehingga peneliti memperoleh data yang diinginkan.

\subsubsection{Terjemahan}

Metode terjemahan digunakan supaya data yang diperoleh mudah dianalisis. Agar pembaca mengerti bentuk penggunaan campur kode dalam pembelajaran bahasa Indonesia di kelas VII SMPN 7 Woja Dompu tahun pelajaran 2016/2017. Adapun data yang akan diperoleh dalam metode terjemahan ini adalah berupa bahasa daerah dan diartikan ke dalam bahasa Indonesia. Lebih khususnya, data penggunaan campur kode dalam pembelajaran bahasa Indonesia di kelas VII SMPN 7 Woja Dompu tahun pelajaran 2016/2017.

Dalam hal ini, yang ditulis adalah kata, frase dan klausa dalam bahasa daerah yang diperoleh, kemudian diterjemahkan ke dalam bahasa Indonesia. Dalam metode ini setelah data terkumpul maka dilakukan alih bahasa, yakni dari bahasa Dompu ke bahasa Indonesia. Adapun alat yang digunakan dalam metode ini adalah buku dan balpoin. Dalam hal ini, buku dan balpoin digunakan untuk mencatat penggunaan campur kode yaitu berupa bahasa Dompu dan bahasa Indonesia. Selanjutnya, peneliti akan mengartikan bahasa Dompu yang digunakan oleh si penutur ke dalam bahasa Indonesia.

\section{HASIL}

Berdasarkan data jumlah siswa menunjukan bahwa jumlah siswa perempuan mendominasi yaitu berjumlah 158, sedangkan siswa laki-laki berjumlah 142 orang. Banyaknya jumlah siswa yang sekolah di SMPN 7 Woja Dompu merupakan tolak ukur kemajuan pendidikan di Kecematan Woja Kabupaten Dompu karena kualitas pendidikan akan terlihat apabila banyaknya anak-anak yang masuk sekolah dan menempuh pendidikan di sekolah.

Tabel 02.Jumlah siswa laki dan perempuan SMPN 7 Woja Dompu.

\begin{tabular}{|c|c|c|c|c|c|c|c|}
\hline \multicolumn{3}{|c|}{ Laki-Laki } & \multicolumn{5}{c|}{ Perempuan } \\
\hline Kelas 7 & Kelas 8 & Kelas 9 & Jumlah & Kelas 7 & Kelas 8 & Kelas 9 & Jumlah \\
\hline $\mathbf{5 5}$ & 35 & 52 & 142 & 54 & 53 & 51 & 158 \\
\hline \multicolumn{3}{|c|}{ Jumlah Laki-Laki + Perempuan } & \multicolumn{3}{|c|}{300} \\
\hline
\end{tabular}




\subsection{Bentuk Campur Kode}

Dengan memperhatikan bahasa ataupun kata-kata yang digunakan oleh guru dan siswa dalam pembelajaran bahasa Indonesia yang biasanya memadukan antara bahasa Indonesia dan bahasa Dompu dalam menjelaskan materinya serta bahasa yang digunakan oleh siswa dalam pembelajaran.

Peristiwa campur kode terjadi karena ketergantungan Penutur terhadap pemakaian bahasa. Demikian pula yang terjadi dalam pembelajaran bahasa Indonesia di kelas VII SMPN 7 Woja Dompu. Guru dan siswa sering mencampurkan bahasa Dompu ke dalam bahasa utama yakni bahasa Indonesia. Berdasarkan data yang diperoleh, berikut ini akan dideskripsikan bentuk-bentuk penggunaan campur kode dalam pembelajaran bahasa Indonesia di kelas VII SMPN 7 Woja Dompu tahun pelajaran 2016/2017.

\section{a. Campur kode berbentuk kata}

Kata adalah deretan huruf yang diapit oleh dua spasi dan mempunyai satu arti (Chaer, 2012:162). Berikut akan diuraikan beberapa bentuk campur kode yang menggunakan kata dalam pembelajaran bahasa Indonsia di kelas VII SMPN 7 Woja Dompu tahun pelajaran 2016/2017.

Campur kode yang dilakukan oleh guru.

(1) "Assalamualaikum warahmatullahi wabarakatuh, baik anak-anak sekarang ndai 'kita' (kata ganti) akan belajar bahasa Indonesia nda $\overline{d i}$ ra tana'o dari pekan

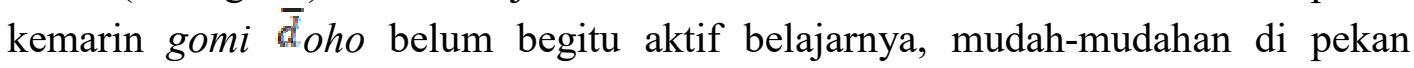
sekarang ini serius tana'o 'belajar' (kata kerja) dan lain sebagainya sehingga proses belajar mengajar kedepannya sudah bisa direalisasikan dan bisa lebih baik. Ndai sanai ake, ta tana'o tentang cerita anak!" (guru/VII.A/1/01/Agustus/2016).

(2) 'Kan sering kade'e 'dengar' (kata kerja) cerita-cerita dari doum tua, tetangga, sa'emu, saudaramu, dan sebagainya sering kalian mendengar, tetapi cerita itu adalah cerita yang bermanfaat $\bar{d} i r u$ 'u $\overline{d a}$ mbe to 'i"' (guru/VII.A/1/01/Agustus/2016).

(3) 'Yaa,,,mpama 'dongeng' (kata benda), pernah gak nggomi do ho ringa cerita douma mpama?” (guru/VII.A/1/01/Agustus/ 2016).

(4) “Ake 'ini' (kata ganti) Ibu pernah dengar dongeng, sering ndai ta ake dengar, di Jawa dan sebaginyapun sering dengar, cerita itu adalah si kancil dan si buaya, sering dengar yah?” (guru/VII.A/1/01/Agustus/ 2016).

(5) “Ede 'itu' (kata ganti) adalah sebuah dongeng” (guru/VII.A/1/01/ Agustus/2016). 
LINGUA, Vol. 16, No. 1, Maret 2019

p ISSN: 1979 9411; e ISSN: 2442 238X

Http://lingua.pusatbahasa.or.id; Email: presslingua@gmail.com

Center of Language and Cultural Studies, Surakarta, Indonesia

Prabowo, Adiprasetio. 2019. Pengaruh Penggunaan Campur Kode dalam Pembelajaran Bahasa Indonesia pada Siswa SMPN 7 Woja Dompu.

Lingua (2019), 16(1): 93 108. DOI: 10.30957/lingua.v16i1.577.

(6) "Ya dou sawatip ndai ntoina, orang belum begini ganteng dan cantiknya, masih seperti kehidupan orang-orang hutan dulu, kalau kita sekarang jaman canggih tinggal kita kutip saja dan hengga 'buka' (kata kerja) buku saja, dou jaman mantoi mpa ma maki fiki ndawi mpama kalau ndai sekarang tinggal hengga buku" (guru/VII.A/1/01/Agustus/2016).

(7) 'Jaman ake 'ini' (kata ganti) sudah canggih, tinggal kani 'pakai' (kata kerja) sepatu, tinggal ngupa piti, sendedempa gomi do ho ake mbuip lawan orang tua, lawan guru, douma ntoi ti lawana guru, ti lawana douma tuana" (guru/VII.A/1/01/Agustus/2016).

(8) "Iya, yang pertama tentukanlah hal yang menarik dan hal yang tidak menarik dari cerita di atas, selain contoh yang telah ada. Yang harus kamu isi, yang kedua setelah kamu membaca cerita tersebut, cerita akanden 'tadi' (kata keterangan waktu)" (guru/VII.A/1/01/Agustus/2016).

(9) 'Ya cerita anak-anakatau bahasa $\overline{d o}$ mpuna 'dompunya' kata keterangan tempat) apa coba?” (guru/VII.B/1/02/Agustus/2016).

(10) 'Ede $\bar{d} \boldsymbol{u}$ 'itulah' (kata ganti) kalau dalam bahasa Indonesia diantaranya adalah dongeng" (guru/VII.B/1/02/Agustus/2016).

Berdasarkan data di atas dapat diketahui bahwa campur kode berbentuk kata yang digunakan oleh guru sebanyak 41 dengan perincian kata benda sebanyak 2, kata kerja sebanyak 9, kata ganti sebanyak 14, kata keterangan sebanyak 8, kata seru sebanyak 2, kata tanya sebanyak 4 kata. Jenis kata yang paling banyak intensitasnya adalah kata ganti sebanyak 16 kata.

Campur kode yang dilakukan oleh siswa.

(1a) “Iyo 'iya' (kata keterangan) Ibuee, benar" (siswa 7/VII.A/1/01/Agustus/ 2016).

(2a) "Iyo 'iya' (kata keterangan) Ibu dia lawan Ibunya" (siswa 12/VII.A/1/01/ Agustus/2016).

(3a) "Iyo 'iya' (kata keterangan) Bu ee" (siswa 7/VII.A/1/01/Agustus/2016).

(4a) "Iyo 'iya' (kata keterangan) Ibu" (siswa 5/VII.A/1/01/Agustus/2016).

(5a) "Iyo 'iya' (kata keterangan) Bu" (siswa serentak/VII.A/1/01/Agustus/2016).

(6a) "Iyo 'iya' (kata keterangan) Ibu ee" (siswa 4/VII.A/1/01/Agustus/2016).

(7a) “Waura 'sudah' (kata keterangan) Ibu” (siswa 9/VII.A/1/01/Agustus/2016).

(8a) “Loa 'bisa' (kata keterangan) Ibu ee" (siswa serentak/VII.A/1/01/Agustus/ 2016).

(9a) “Loa 'bisa' (kata keterangan) Ibu ee” (siswa 7/VII.A/1/01/Agustus/2016). 
LINGUA, Vol. 16, No. 1, Maret 2019

p ISSN: 1979 9411; e ISSN: 2442 238X

Http://lingua.pusatbahasa.or.id; Email:presslingua@gmail.com

Center of Language and Cultural Studies, Surakarta, Indonesia

Prabowo, Adiprasetio. 2019. Pengaruh Penggunaan Campur Kode dalam Pembelajaran Bahasa Indonesia pada Siswa SMPN 7 Woja Dompu.

Lingua (2019), 16(1): 93 108. DOI: 10.30957/lingua.v16i1.577.

(10a) “Apakah sama judul $\boldsymbol{l a}^{\overline{\boldsymbol{b}}} \boldsymbol{o}$ 'dengan' (kata sambung) pokok cerita Ibu?” (siswa 15/VII.A/1/01/Agustus/2016).

Berdasarkan data di atas dapat diketahui bahwa campur kode berbentuk kata yang digunakan oleh siswa sebanyak 54 dengan perincian kata benda sebanyak 1, kata kerja sebanyak 1, kata ganti sebanyak 7, kata ketarangan sebanyak 35, kata bilangan sebanyak 2, kata sambung sebanyak 1, kata depan sebanyak 2, kata sandang sebanyak 1 , kata seru sebanyak 1, kata tanya sebanyak 1 kata. Jenis kata yang paling banyak intensitasnya adalah kata keterangan sebanyak 37 kata. Jadi, lebih banyak jumlah penggunaan campur kode berbebntuk kata yang dilakukan oleh siswa daripada guru bahasa Indonesia, sedangkan jumlah keseluruhan campur kode berbentuk kata yang dilakukan oleh guru dan siswa dalam pembelajaran bahasa Indonesia di kelas VII.A dan VII.B adalah sebanyak 95 kata.

\section{b. Campur kode berbentuk frase}

Menurut Alwi (2003:312), frase adalah satuan sintaksis yang terdiri atas dua kata atau lebih yang tidak megandung unsur predikasi. Sedangkan menurut (Verhar, 2004:291) menyatakan frase adalah kelompok kata yang merupakan bagian fungsional dari tuturan yang lebih panjang.

Campur kode yang dilakukan oleh guru.

(11) "Assalamualaikum warahmatullahi wabarakatuh, baik anak-anak sekarang ndai akan belajar bahasa Indonesia nda $\bar{d} \boldsymbol{i}$ ra tana'o 'jadi yang dipelajari' (frase eksosentrik) dari pekan kemarin nggomi $\bar{d}$ o ho 'kalian semua' (frase koordinatif) belum begitu aktif belajarnya, mudah-mudahan di pekan sekarang ini serius tana'o dan lain sebagainya sehingga proses belajar mengajar kedepannya sudah bisa direalisasikan dan bisa lebih baik. Ndai sanai ake, ta tana'o tentang cerita anak!” (guru/VII.A/1/02/Agustus/2016).

(12) Ause $\bar{d}$ i nggahi kaina 'apa sih dikatakan' (frase apositif) cerita anak itu?" (guru/VII.A/1/02/Agustus/2016).

(13) "Ya cerita $\bar{d} a$ mbe to' $i$, $\bar{d}_{\text {tr }} r$ 'u $\bar{d} a$ mbe to'i. Mbune nggomi $\bar{d}$ o ho ake, $\bar{b}_{\text {une }}$ $\overline{\boldsymbol{d}} \boldsymbol{a} \boldsymbol{m b e}$ to'i 'seperti kalian ini, seperti anak kecil' (frase endosentrik) umur 5 tahun sudah mengenal cerita ya, 6 tahun 7 tahun sampe $\bar{b}$ une nggomi do ho ake $\boldsymbol{y a}$ 'sampai seperti kalian ini ya' (frase endosentrik)" (guru/VII.A/1/02/ Agustus/2016).

(14) "Dongeng ause gahi mbojona 'apa sih bahasa bimanya' (frase endosentrik) dongeng?" (guru/VII.A/1/02/Agustus/2016). 
LINGUA, Vol. 16, No. 1, Maret 2019

p ISSN: 1979 9411; e ISSN: 2442 238X

Http://lingua.pusatbahasa.or.id; Email: presslingua@gmail.com

Center of Language and Cultural Studies, Surakarta, Indonesia

Prabowo, Adiprasetio. 2019. Pengaruh Penggunaan Campur Kode dalam Pembelajaran Bahasa Indonesia pada Siswa SMPN 7 Woja Dompu.

Lingua (2019), 16(1): 93 108. DOI: 10.30957/lingua.v16i1.577.

(15) "Ya dou sawatip ndai ntoina 'orang sebelum kita dulu' (frase apositif), orang belum begini ganteng dan cantiknya, masih seperti kehidupan orang-orang hutan dulu, kalau kita sekarang jaman canggih tinggal kita kutip saja dan hengga buku saja, dou jaman mantoi mpa ma maki fiki ndawi mpama kalau ndai sekarang tinggal hengga buku 'buka buku' (frase eksosentrik)" (guru/VII.A/1/02/Agustus/2016).

Berdasarkan data di atas dapat diketahui bahwa campur kode berbentuk frase yang digunakan oleh guru sebanyak 63 dengan perincian frase eksosentrik sebanyak 24 , frase endosentrik sebanyak 22, frase koordinatif sebanyak 14, frase apositif sebanyak 4. Jenis frase yang paling banyak intesitasnya adalah frase eksosentrik sebanyak 24 kata.

Campur kode yang dilakukan oleh siswa.

(11a) "Cerita $\overline{\boldsymbol{d}} \boldsymbol{\alpha}$ mbe to'i 'anak kecil' (frase koordinatif) Ibu e" (siswa 4/ VII.A/1/02/Agustus/2016).

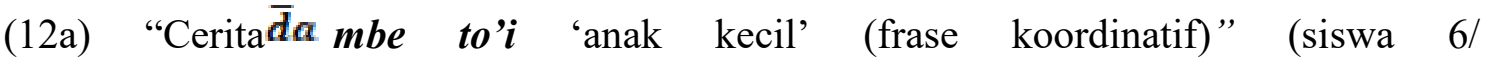
VII.A/1/02/Agustus/2016).

(13a) "Karawo lambo ngao 'tikus dan kucing' (frase koordinatif) Ibu" (siswa 3/ VII.A/1/02/Agustus/2016).

(14a) "Honda do hona 'motor juga' (frase endosentrik) Bu ee" (siswa 3/ VII.A/1/02/Agustus/2016).

(15a) 'Sara'a ti wara dou ma ntoi 'serba tidak ada orang dulu' (frase endosentrik) Ibu e" (siswa 4/VII.A/1/02/Agustus/2016).

(16a) "Pahumpa canggihna 'itulah canggihnya' (frase eksosentrik) teknologi de Ibu" (siswa1/VII.A/1/02/Agustus/2016).

(17a) “Loa ka ao 'bisa mengerti' (frase koordinatif) Ibu ee” (siswa 3/VII.A/1/02/ Agustus/2016).

(18a) “Ta da maina 'di sebelah kanan' (frase endosentrik) Ibu e” (siswa 11/ VII.A/1/02/Agustus/2016).

(19a) “Ma $\bar{b}_{\text {ena }}$ 'yang mana' (frase eksosentrik) Ibu e” (siswa 20/VII.A/1/02/ Agustus/2016).

(20a) "Cerita $\overline{\boldsymbol{d}} \boldsymbol{a}$ mbe to'i 'anak kecil' (frase koordinatif)" (siswa 3/VII.B/1/02/ Agustus/2016). 
LINGUA, Vol. 16, No. 1, Maret 2019

p ISSN: 1979 9411; e ISSN: 2442 238X

Http://lingua.pusatbahasa.or.id; Email: presslingua@gmail.com

Center of Language and Cultural Studies, Surakarta, Indonesia

Prabowo, Adiprasetio. 2019. Pengaruh Penggunaan Campur Kode dalam Pembelajaran Bahasa Indonesia pada Siswa SMPN 7 Woja Dompu.

Lingua (2019), 16(1): 93 108. DOI: 10.30957/lingua.v16i1.577.

Berdasarkan data di atas dapat diketahui bahwa campur kode berbentuk frase yang digunakan oleh siswa sebanyak 44 dengan perincian frase eksosentrik sebanyak 15, frase endosentrik sebanyak 13, frase koordinatif sebanyak 9, frase apositif sebanyak 7. Jenis frase yang paling banyak intesiitasnya adalah frase eksosentrik sebanyak 25 kata. Jenis frase yang paling banyak intesitasnya adalah frase endosentrik 17 frase. Jadi, lebih banyak penggunaan campur kode berbentuk frase yang dilakukan oleh guru daripada siswa, sedangkan jumlah keseluruhan campur kode berbentuk frase yang di lakukan oleh guru dan siswa dalam pembelajaran bahasa Indonesia di kelas VII.A dan VII.B adalah sebanyak 107 frase.

\section{c. Campur kode berbentuk klausa}

Menurut Alwi (2003:39) menyatakan istilah klausa dipakai untuk merujuk pada deretan kata yang paling tidak memiliki subjek dan predikat, tetapi belum memiliki intonasi atau tanda baca tertentu.

Campur kode yang dilakukan oleh guru.

(21) "Ya cerita $\bar{d} a$ mbe to'i $\bar{d} i$ ru'u $\bar{d} a$ mbe to'i, $\bar{b}$ une nggomi do ho ake 'anak kecil untuk anak kecil, seperti kalian ini' (klausa tergabung koordinatif), $\bar{b}_{\text {une }}$ $\bar{d}$ da mbe to' $i$ umur 5 tahun sudah mengenal cerita ya, 6 tahun 7 tahun sampe $\overline{b u}_{n e}$ nggomi do ho ake ya" (guru/VII.A/1/02/Agustus/2016).

(22) "Kan sering kade'e cerita-cerita dari doum tua, tetangga, sa'emu, saudaramu, dan sebagainya sering kalian mendengar, tetapi cerita itu adalah cerita yang bermanfaat ndi ru'u $\bar{d} \boldsymbol{a}$ mbe to'i 'untuk anak kecil' (klausa tergabung subordinatif)" (guru/VII.A/1/02/Agustus/2016).

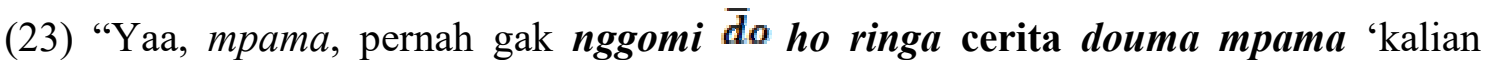
dengar cerita orang yang berdongeng' (klausa bebas?)" (guru/VII.A/ 1/02/Agustus/2016).

(24) "Semua di dunia ini pernah mengetahui mpama ede $\bar{d} \boldsymbol{u}$ untuk menghibur anaanana, mane'e maru kombi, anana mabengke kombi dongeng ialah untuk menghibur anak-anak, yang ingin tidur dan anak yang nakal' (klausa tergabung subordinatif), na adakanlah mpama" (guru/VII.A/1/02/ Agustus/2016).

(25) "Termasuk $\bar{d}$ ru'u nggomi $\bar{d} o$ ho. Cerita ma caru ru'u nggomi do ho re, misal cerita $\bar{d} \boldsymbol{o}$ te $\boldsymbol{l a} \overline{\boldsymbol{b}}_{\boldsymbol{o}}$ karefa 'yang bagus untuk kalian, misal cerita monyet dan kodok' (klausa apositif). Au wali?” (guru/VII.A/1/02/Agustus/2016).

(26) "Dongeng ake laina ra nda $\bar{d} i$ na ai jaman-jaman ake, tapi ra nda $\bar{d} i$ ai jamanjaman 'ini bukan terjadi pada jaman-jaman sekarang, tapi terjadi pada jaman- 
LINGUA, Vol. 16, No. 1, Maret 2019

p ISSN: 1979 9411; e ISSN: 2442 238X

Http://lingua.pusatbahasa.or.id; Email:presslingua@gmail.com

Center of Language and Cultural Studies, Surakarta, Indonesia

Prabowo, Adiprasetio. 2019. Pengaruh Penggunaan Campur Kode dalam Pembelajaran Bahasa Indonesia pada Siswa SMPN 7 Woja Dompu.

Lingua (2019), 16(1): 93 108. DOI: 10.30957/lingua.v16i1.577.

jaman' (klausa negatif) dulu ede $\bar{d} u$ jaman nenek moyang ndai, Ause nene moyang re?" (guru/VII.A/1/02/Agustus/2016).

(27) "Ya dou sawatip ndai ntoina, orang belum begini ganteng dan cantiknya, masih seperti kehidupan orang-orang hutan dulu, kalau kita sekarang jaman canggih tinggal kita kutip saja dan hengga buku saja, dou jaman ma ntoi mpa ma maki fiki ndawi mpama' orang jaman dulu saja yang capek mikir membuat dongeng' (klausa bebas) kalau ndai sekarang tinggal hengga buku" (guru/VII.A/1/02/Agustus/2016).

(28) "Douma ntoina ti wara TVna tiwara HPna 'orang dulu tidak punya $T V$, tidak punya HP' (klausa negatif)” (guru/VII.A/1/02/Agustus/2016).

(29) "Yadou ma ntoi cuman wara mpama $\overline{d i}$ ma hiburna 'ya orang dulu cuman ada dongeng yang akan menghiburnya' (klausa bebas)" (guru/VII.A/1/02/ Agustus/2016).

(30) “Assalamualaikum warahmatullahi wabarakatuh, ndai sanai ake ta tana'o ra tana'o minggu ma ulu 'kita hari ini akan belajar yang dipelajari minggu yang lalu' (klausa verbal) kalian belum begitu aktif belajarnya. Mudah-mudahan di pekan sekarang ini serius tana'o mena. Sudah bisa direalisasikan dan bisa lebih baik. Kita hari ini akan belajar tentang cerita anak, apasi dikatakan cerita anak itu?" (guru/VII.B/1/02/Agustus/2016).

Berdasarkan data di atas dapat diketahui bahwa campur kode berbentuk klausa yang digunakan oleh guru sebanyak 30 dengan perincian klausa bebas sebanyak 11, klausa terikat sebanyak 2, klausa negatif sebanyak 5, klausa apositifsebanyak 3, klausa verbal sebanyak 2, klausa mandiri sebanyak 2, klausa tergabung koordinatif sebanyak 1 , klausa tergabung subordinatif sebanyak 4 klausa. Jenis klausa yang paling banyak intesitasnya adalah klausa bebas sebanyak 11 klausa.

Campur kode yang dilakukan oleh siswa sebagai berikut.

(21a) "Iyo Bu e, ngaompa ma roi weki 'kucing saja yang puji diri sendiri' (klausa nonverbal) ndaina" (siswa 5/VII.B/1/02/Agustus/2016).

(22a) "Sara'a tiwara douma ntoi 'serba tidak ada orang dulu' (klausa negatif) Ibu e" (siswa 4/VII.B/1/02/Agustus/2016).

(23a) "Pernah $B u$, sia dosana aka dou ma tuana 'dia dosa pada orang tuanya' (klausa bebas)" (siswa 7/VII.B/1/02/Agustus/2016).

(24a) 'Ringa cowa ra ringa poda nggomi 'dengar bohong atau dengar benar kamu' (klausa tergabung koordinatif) Asti?” (siswa 7/VII.A/2/ 02/Agustus/2016). 
LINGUA, Vol. 16, No. 1, Maret 2019

p ISSN: 1979 9411; e ISSN: 2442 238X

Http://lingua.pusatbahasa.or.id; Email: presslingua@gmail.com

Center of Language and Cultural Studies, Surakarta, Indonesia

Prabowo, Adiprasetio. 2019. Pengaruh Penggunaan Campur Kode dalam Pembelajaran Bahasa Indonesia pada Siswa SMPN 7 Woja Dompu.

Lingua (2019), 16(1): 93 108. DOI: 10.30957/lingua.v16i1.577.

(25a) "Dou ma ntoi tunti kani auku dongeng re Ibu $\boldsymbol{e}^{\text {‘ }}$ orang dulu tulis pakai apa dongeng Ibu'? (klausa nonverbal)” (siswa 3/VII.A/2/02/Agustus/2016).

(26a) "Ibu jangan cuman bilang sama saya $\mathrm{Bu}$, la Dewi rau pernah ngahana di kelas awin re 'si Dewi juga pernah makan di kelas kemarin itu' (klausa bebas)" (siswa 3/VII.A/2/02/Agustus/2016).

(27a) "Iya $\mathrm{Bu}$, mada pernaku ringa dou ma cerita 'saya pernah dengar orang yang cerita' (klausa bebas) bahwa klub sepak bola Naga FC pernah mendapatkan juara aka Desa Serakapi Bu" (siswa 4/VII.A/2/02/Agustus/2016).

(28a) "Mada laoku ndiha aka air terjun 'saya pergi rekreasi di air terjun' (klausa bebas) hari Minggu kemarin” (siswa 15/VII.A/2/02/Agustus/2016).

(29a) 'Oee Ardilan lu'u baca ulu nggomi 'oee Ardilan masuk baca dulu kamu' (klausa mandiri) kare" (siswa 3/VII.A/2/02/Agustus/2016).

(30a) “Watip lu'una Ibu, waura lao'belum masuk Ibu, sudah pergi' (klausa negatif) ijin" (siswa 4/VII.B/2/02/Agustus/2016).

Berdasarkan data di atas dapat diketahui bahwa campur kode berbentuk klausa yang digunakan oleh siswa sebanyak 13 dengan perincian klausa bebas sebanyak 4, klausa terikat sebanyak, klausa negatif sebanyak 3, klausa verbal sebanyak 1, klausa nonverbal sebanyak 2, klausa mandiri sebanyak, klausa tergabung koordinatif sebanyak 1 klausa. Jenis klausa yang paling banyak intesitasnya adalah klausa bebas sebanyak 4 klausa. Jadi, lebih banyak penggunaan campur kode berbentuk klausa yang dilakukan oleh guru daripada siswa, sedangkan jumlah keseluruhan campur kode berbentuk klausa yang dilakukan oleh guru dan siswa dalam pembelajaran bahasa Indonesia di kelas VII.A dan VII.B adalah sebanyak 43 klausa.

\subsection{Pengaruh Penggunaan Campur Kode dalam Pembelajaran Bahasa Indonesia}

Berdasarkan data hasil wawancara siswa kelas VII.A dan VII.B dengan jumlah siswa sebanyak 54 orang dan 1 orang guru bahasa Indonesia yang telah dilampirkan. Berikut ini akan dipaparkan jumlah dan presentase siswa serta guru yang menjawab wawancara tentang pengaruh penggunaan campur kode dalam pembelajaran bahasa Indonesia di kelas VII SMPN 7 Woja Dompu tahun pelajaran 2016/2017.

1. Hasil wawancara siswa

a. Siswa aktif

\begin{tabular}{|llll|}
\hline Siswa & Aktif & Tidak aktif & Biasa saja \\
\hline Jumlah siswa & 15 & - & 39 \\
\hline Presentase & $28 \%$ & $0 \%$ & $72 \%$ \\
\hline
\end{tabular}


LINGUA, Vol. 16, No. 1, Maret 2019

p ISSN: 1979 9411; e ISSN: 2442 238X

Http://lingua.pusatbahasa.or.id; Email:presslingua@gmail.com

Center of Language and Cultural Studies, Surakarta, Indonesia

Prabowo, Adiprasetio. 2019. Pengaruh Penggunaan Campur Kode dalam Pembelajaran Bahasa Indonesia pada Siswa SMPN 7 Woja Dompu.

Lingua (2019), 16(1): 93 108. DOI: 10.30957/lingua.v16i1.577.

Jadi, intesitas penggunaan campur kode tidak berpengaruh dalam pembelajaran bahasa Indonesia di kelas VII SMPN 7 Woja Dompu tahun pelajaran 2016/2017, karena jumlah siswa yang aktif adalah sebanyak 28\% sedangkan siswa yang tidak aktif sebanyak $72 \%$ dari jumlah keseluruhan siswa sebanyak 54 orang.

b. Siswa paham/mengerti

\begin{tabular}{|llll|}
\hline Siswa & $\begin{array}{l}\text { Paham dan } \\
\text { mengerti }\end{array}$ & $\begin{array}{l}\text { Tidak paham } \\
\text { dan mengerti }\end{array}$ & Biasa saja \\
\hline Jumlah siswa & 17 & 3 & 34 \\
\hline Presentase & $31 \%$ & $6 \%$ & $63 \%$ \\
\hline
\end{tabular}

Jadi, intesitas penggunaan campur kode tidak berpengaruh dalam pembelajaran bahasa Indonesia di kelas VII SMPN 7 Woja Dompu tahun pelajaran 2016/2017, karena jumlah siswa yang paham/mengerti adalah sebanyak 31\% sedangkan siswa yang tidak paham/mengerti sebanyak $69 \%$ dari jumlah keseluruhan siswa sebanyak 54 orang.

c. Siswa cepat tanggap

\begin{tabular}{|llll|}
\hline Siswa & Cepat tanggap & Tidak tanggap & Biasa saja \\
\hline Jumlah siswa & 1 & - & 53 \\
\hline Presentase & $2 \%$ & $0 \%$ & $98 \%$ \\
\hline
\end{tabular}

Jadi, intensitas penggunaan campur kode tidak berpengaruh dalam pembelajaran bahasa Indonesia di kelas VII SMPN 7 Woja Dompu tahun pelajaran 2016/2017, karena jumlah siswa yang cepat tanggap adalah sebanyak $2 \%$ sedangkan siswa yang tidak cepat tanggap sebanyak 98\% dari jumlah keseluruhan siswa sebanyak 54 orang.

d. Siswa lebih familiar

\begin{tabular}{|clll|}
\hline Siswa & Lebih familiar & Tidak familiar & Biasa saja \\
\hline Jumlah siswa & 7 & 4 & 43 \\
\hline Presentase & $13 \%$ & $7 \%$ & $80 \%$ \\
\hline
\end{tabular}

Jadi, intesitas penggunaan campur kode tidak berpengaruh dalam pembelajaran bahasa Indonesia di kelas VII SMPN 7 Woja Dompu tahun pelajaran 2016/2017, karena jumlah siswa yang lebih familiar adalah sebanyak 13\% sedangkan siswa yang tidak familiar sebanyak $87 \%$ dari jumlah keseluruhan siswa sebanyak 54 orang.

e. Siswa konsentrasi

\begin{tabular}{|cccc|}
\hline Siswa & Konsentrasi & Tidak konsentrasi & Biasa saja \\
\hline Jumlah siswa & 1 & 5 & 48 \\
\hline Presentase & $2 \%$ & $9 \%$ & $89 \%$ \\
\hline
\end{tabular}


LINGUA, Vol. 16, No. 1, Maret 2019

p ISSN: 1979 9411; e ISSN: 2442 238X

Http://lingua.pusatbahasa.or.id; Email:presslingua@gmail.com

Center of Language and Cultural Studies, Surakarta, Indonesia

Prabowo, Adiprasetio. 2019. Pengaruh Penggunaan Campur Kode dalam Pembelajaran Bahasa Indonesia pada Siswa SMPN 7 Woja Dompu.

Lingua (2019), 16(1): 93 108. DOI: 10.30957/lingua.v16i1.577.

Jadi, intesitas penggunaan campur kode tidak berpengaruh dalam pembelajaran bahasa Indonesia di kelas VII SMPN 7 Woja Dompu tahun pelajaran 2016/2017, karena jumlah siswa yang konsentrasi adalah sebanyak 13\%sedangkan siswa yang tidak konsentrasi sebanyak 98\% dari jumlah keseluruhan siswa sebanyak 54 orang.

\section{PEMBAHASAN}

Berdasarkan data yang diperoleh dari hasil penelitian yang telah dideskripsikan di atas, maka ditemukan bentuk penggunaan campur kode dalam pembelajaran bahasa Indonesia di kelas VII SMPN 7 Woja Dompu tahun pelajaran 2016/2017 yaitu campur kode berbentuk kata, frase, dan klausa. Data campur kode berbentuk frase mendominasi dalam penelitian ini yaitu berjumlah 107 frase, selain data yang berwujud frase terdapat data yang berbentuk kata berjumlah 95 kata, terdapat juga data campur kode berbentuk klausa berjumlah 43 klausa, intesitas kemunculanya tidak terlalu banyak. Data penggunaan campur kode dalam pembelajaran penelitian ini lebih banyak intesitas penggunaan campur kode oleh guru daripada siswa sehingga dalam pembelajaran berlangsung secara aktif menggunakan dua bahasa.

Selain itu, hasil penelitian tentang pengaruh penggunaan campur kode dalam pembelajaran bahasa Indonesia menunjukan guru mata pelajaran bahasa Indonesia mengatakan bahwapenggunaan campur kode dapat memperlancar dan memberikan manfaat yang signifikan saat berlangsungnya pembelajaran bahasa Indonesia di kelas VII SMPN 7 Woja Dompu tahun pelajaran 2016/2017. Pernyataan dari guru mata pelajaran bahasa Indonesia tentang pengaruh penggunaan campur kode dalam pembelajaran tersebut berbeda jauh dengan pendapat siswa yang terdiri dari 54 siswa. Adapun siswa yang mengatakan merasa aktif sebanyak $28 \%$, siswa yang paham/mengerti sebanyak $31 \%$, siswa yang cepat tanggap sebanyak $2 \%$, siswa yang lebih familiar sebanyak $13 \%$, dan siswa yang konsetrasi $2 \%$, dari keseluruhan siswa sebanyak 54 orang baru dikatakan mencapai $100 \%$.

Penggunaan campur kode dalam pembelajaran bahasa Indonesia juga ada sebagian siswa yang tidak aktif sebanyak $0 \%$, siswa yang mengatakan merasa biasa saja aktif sebanyak $72 \%$, siswa yang tidak paham/mengerti sebanyak $6 \%$, siswa yang biasa saja paham/mengerti sebanyak $63 \%$, siswa yang tidak cepat tanggap sebanyak $0 \%$, siswa biasa saja cepat tanggap sebanyak 98\%, siswa yang tidak familiar sebanyak $7 \%$, siswa yang baisa saja familiar sebanyak $80 \%$ dan siswa yang tidak konsetrasi sebanyak $9 \%$, siswa yang biasa saja konsentrasi sebanyak $89 \%$. Jadi, pengaruh penggunaan campur kode dalam pembelajaran bahasa Indonesia lebih mendominasi siswa biasa saja. Hal ini menunjukan bahwa tidak ada pengaruh penggunaan campur kode dalam pembelajaran bahasa Indonesia siswa kelas VII SMPN 7 Woja Dompu tahun pelajaran 2016/2017.

\section{SIMPULAN}

Berdasarkan hasil analisis dan pembahasan mengenai penggunaan campur kode dalam pembelajaran bahasa Indonesia di kelas VII SMPN 7 Woja Dompu tahun pelajaran 2016/2017, maka dapat disimpulkan sebagai berikut. 
LINGUA, Vol. 16, No. 1, Maret 2019

p ISSN: 1979 9411; e ISSN: 2442 238X

Http://lingua.pusatbahasa.or.id; Email:presslingua@gmail.com

Center of Language and Cultural Studies, Surakarta, Indonesia

Prabowo, Adiprasetio. 2019. Pengaruh Penggunaan Campur Kode dalam Pembelajaran Bahasa Indonesia pada Siswa SMPN 7 Woja Dompu.

Lingua (2019), 16(1): 93 108. DOI: 10.30957/lingua.v16i1.577.

1. Bahwa ditemukan bentuk penggunaan campur kode berbentuk kata, frase dan klausa. Data penggunaan campur kode berbentuk kata berjumlah 95 kata, campur kode berbentuk frase berjumlah 107 frase, campur kode berbentuk klausa berjumlah 43 klausa. Penggunaan campur kode yang mendominasi dalam penelitian ini adalah campur kode berbentuk frase.

2. Pengaruh penggunaan campur kode dalam pembelajaran bahasa Indonesia di kelas VII SMPN 7 Woja Dompu tahun pelajaran 2016/2017 adalah bahwa bagi guru penggunaan campur kode memberikan pengaruh yang signifikan dan memperlancar berlangungnya pembelajaran, sedangkan bagi siswa penggunaan campur kode tidak berpengaruh dalam pembelajaran bahasa Indonesia di kelas VII SMPN 7 Woja Dompu tahun pelajaran 2016/2017.

\section{DAFTAR PUSTAKA}

Alwi, H. 2003. Tata Bahasa Baku Bahasa Indonesia. Jakarta: Balai Pustaka.

Arikunto. 2006. Prosedur Penelitian Suatu Pendekatan Praktik. Jakarta: Rineka Cipta.

Aslinda dan Syafyahya, L. 2010. Pengantar Sosiolinguistik. Bandung: PT Refika Aditama.

Chaer, A. 2012. Lingustik Umum. Jakarta: Rineka Cipta.

Dimyati dan Mudjiono. 2015. Belajar dan pembelajaran. Jakarta: Rineka Cipta.

Furkhan, A. 2004. Pengantar Penelitian dalam Pendidikan. Yogyakarta: Pustaka Pelajar.

Halim, A. 1976. Politik Bahasa Nasional. Jakarta: Pusat Pembinaan dan Pengembangan

Bahasa, Departemen Pendidikan dan Kebudayaan.

Mahsun. 2013. Metode Penelitian Bahasa Tahapan Strategi, Metode, dan Tekniknya. Jakarta: Rajawali Pers.

Mulyana, D. 2016. Ilmu Komunikasi Suatu Pengantar. Bandung: PT Remaja Rosdakarya.

Rahman, H. 2013. Analisis Tindak Bahasa Campur Kode Di Pasar Labuhan Sumbawa Pendekatan Sosiolinguistik. Skripsi-FKIP: Universitas Muhammadiyah Mataram.

Sukardi. 2010. Metodologi Penelitian Pendidikan. Jakarta: Bumi Aksara.

Suharsaputra, U. 2012. Metode Penelitian. Bandung: PT Refika Aditama.

Sugiyono. 2014. Metode Pendidikan Pendekatan Kuantitatif, Kualitatif, dan R\&D. Bandung: CV Alfabet.

Verhaar, J.W.M. 2004. Asas-Asas Linguistik Umum. Yogyakarta: Gadjah Mada University Press. 
LINGUA, Vol. 16, No. 1, Maret 2019

p ISSN: 1979 9411; e ISSN: 2442 238X

Http://lingua.pusatbahasa.or.id; Email: presslingua@gmail.com

Center of Language and Cultural Studies, Surakarta, Indonesia

Prabowo, Adiprasetio. 2019. Pengaruh Penggunaan Campur Kode dalam Pembelajaran

Bahasa Indonesia pada Siswa SMPN 7 Woja Dompu.

Lingua (2019), 16(1): 93 108. DOI: 10.30957/lingua.v16i1.577. 